\title{
Obama and Transformation Strategy from the Middle East to the Asia - Pacific Region
}

\author{
Mohamed Kamal $^{1} \&$ Khalid Hashim Mohammed ${ }^{1}$ \\ ${ }^{1}$ Faculty of Economic and Political Science, Cairo University, Egypt \\ Correspondence: Khalid Hashim Mohammed. Email: Khalid_khd1900@yahoo.com
}

Received: February 1, 2017

Accepted: March 8, 2017 Online Published: May 31, 2017

doi:10.5539/ass.v13n6p46

URL: https://doi.org/10.5539/ass.v13n6p46

\begin{abstract}
The Middle East region is no longer enjoys the relative importance for the United States. This was due to the massive discoveries of Shale oil in the United States. Many analysts believe that such discovery led to the decline of the US interest in the Middle East and shifting the orientation towards Asia because of the growing importance of the Southeast Asia in the global economy. The United States, in return, has re-defined the role and the size of involvement in the Middle East by adopting a new strategy based on reducing economic and military consequences resulting from the direct investment in the region, which is rejected by US public opinion.
\end{abstract}

\section{The Importance of Subject}

The significance of subject stems from the obvious difference between the policies of ex-president Barack Obama and the current president Donald Trump towards Asia-Pacific region. The Trump Administration has stated that it would reconsider the US policy towards Asia- Pacific region. Therefore, it is important to recognize and grasp all Obama's justifications for going to Asia- Pacific region to determine to what extent the US interests could be affected (positively or negatively) in this vital region by Trump's policies.

Upon the arrival of Barack Obama to Power, the Middle East received a Priority in his Foreign Policy. He announced his intention to adopt an active policy towards the Middle East issues. In the first weeks of taking office as President, he set a time table for withdrawing of US troops from Iraq. In addition, he appointed a negotiator for peace in the Middle East in an attempt to resolve the Israeli - Palestinian conflict and open a new page with the Islamic world. Therefore, he sought to adopt policies that support the aspirations of the region's peoples in development and democracy. Furthermore, he has abandoned his commitment to send troops to Afghanistan, and he has sought to get closer to Iran by sending a message to Iran on the occasion of "Nayrous Feast", which included mention explicitly to the Islamic Republic of Iran. In fact, these policies have been a preliminary stage taken by Obama to withdraw from the Middle East gradually. It is no longer attractive to US decision makers. The then global economic developments made president Obama compelled to redraw the future orientations of the US foreign policy. The American society has been suffering from the repercussions of the global financial crisis that shook the global economy in 2008. Also, it involved in solving the Middle East's crises militarily. These matters resulted in the expanding and complexity of the US role. It has planned to wage limited wars to achieve specific objectives under the slogan of fighting against terrorism and promoting democracy. The two slogans adopted by the United States as targets for its wars in the Middle East. The US found itself bears political, economic and military burdens that cannot face them individually. Therefore, Obama promised to finalize the US wars in the Middle East and to reduce the military presence in the region. Additionally, Obama promised to turn the US orientation towards issues which are beneficial to the US economy, which has suffered heavy losses due to the strategic and military policies adopted by the US in the aftermath of September 11, 2001. Obama has redefined the circles of concerns of the US foreign policy that he focused on during his presidential term to achieve his desired objectives (1). Obama saw that the time of transformation from the Middle East to Asia- Pacific region has come. This trend called Asia rebalance. The new policy aimed to increase the US engagement in this promising region, to maximize the future opportunities, and to mobilize its resources to serve the new economic challenges (2).

In January 2012, the White House released an important strategic document talking about shifting in the priorities of the United States from the Middle East and Europe to the Asia - Pacific Region. Consequently, the US interest in the Middle East retreated, especially in the last years of the Obama Administration. In turn, the 
American interest in Asia, whether to participate in the fruits of growth in this promising continent economically, or to counter the escalation of China's strategic influence in it, which threatens the American presence in Asia. This matter has become the main approach of the United States, and led to what is known as " the strategy of rebalancing towards Asia - Pacific region(3).

Therefore, the study's main question is raised, which is: what is the strategy of the transformation from the Middle East to Asia- Pacific region? And what are the reasons of this transition and its dimensions and consequences? Some sub questions have emanated from this main question, which are:

What are the reasons of disengagement in the Middle East and turning towards Asia- Pacific region?

What are the stages of US re-position in the Middle East as a preliminary step for withdrawal?

What are the dimensions of the US orientation towards Asia- Pacific region?

\subsection{First: The American Disengagement in the Middle East}

The new developments, whether related to the situation in the Middle East region, particularly after the revolutions of the Arab Spring, or those related to the orientations of the United States, the adoption of a new approach in foreign policy by the United States. It has transformed from the intensive engagement to the flexible one. Therefore, the US intervention in the Middle East became cautious, which will be explained by the following developments:

1-The need of the United States the Middle East's Oil has declined due to the diversity of oil's import sources, and relying more on sources from outside of the Gulf region such as Canada, Mexico and Nigeria. In addition, the emergence what is called "Shale Oil" in the United States, and starting in its extraction and production according to economic criteria. It is expected that the United States will be self - sufficient in the near future. According to estimates, the United States will achieve this Self - sufficiency by 2020, and will become an exporter of oil during the period from 2025 to 2030. Thus, the United States will not need for oil imports from abroad, especially the Middle East (4).

This Development has become one of the fundamental inputs in the American strategic thinking towards the Middle East region to which its historical existence related in order to secure oil resources to the American markets. Therefore, the decline of the American need for the region's oil will affect certainly the degree of its interest in the Middle East and related to it.

2- The US military spending has been reduced. In the light of the high budget deficit, the pressures that faced the Obama Administration to reduce the military spending, and reducing the budget of Ministry of Defense, it is difficult to get involved in new wars in the Middle East and continue in the case of the exhaustion. Furthermore, increasing the levels of instability in the Middle East led to the reformulation of the strategic aims of the American interests. The traditional targets of the United States are to maintain the flow of oil, the security of Israel, preventing the nuclear proliferation, and facing the Russian influence. However, focus became presently on how to achieve stability and to counter the rise of the terrorist movements.

Rethinking in dealing with the Middle East region and moving towards the adoption of a restricting strategy which serves the new US interests emerged in many aspects. For example, the continuity of adherence to the option of non - military involvement in the region, focus on dealing with the crises of the region selectively and not to adopt a comprehensive strategy, and the American interest in making the region's countries deal with their issues and crises directly without relying on the American role. Besides, the change of the strategic environment of the territory led to the transformation of the US - Iran relations from the status of hostility to cooperation, and then relation normalization on long - term.

It seemed clear that this change and transition from intensive engagement to flexible one do not correspond with the interests of the influential regional powers in the Middle East. Therefore, relations between these regional powers and the United States have entered a new phase. The traditional alliance mixed with skepticism concerning the orientations of the US administration. There was much talk in the United States' decision making circles, think tanks and media about the American withdrawal from the region. For this, these regional powers, especially the Arab ones, reformulated their alliances with the other international powers (5).

3- The disengagement of the United States from the Middle East in the Obama presidential term was also a reflection of the trends of the American public opinion that it is no longer enthusiastic about US involvement in the region due to the huge costs the United States suffered in the invasion and occupation of Iraq. In addition to that Obama and many American decision making circles were convinced that the United States ability to affect the course of events in the Middle East has become limited, and the majority of political forces in the region do 
not want such the United States' influence. This emerged clearly in the American limited role and influence after the Arab Spring, and refusing a wide range of public opinion and different political forces in the Arab countries for any role the United States can play. Also, lack of credibility and skepticism about the United States' intentions. Consequently, the United States is aware of the limited role that can play in the region, and this role does not welcome. Some American government circles have had convictions that the United States does not need to play such role.

Accordingly, a number of strategic thinkers and think tanks believe that the Middle East is suffering from instability that will continue for several years, and it is best not to interfere. Some described this condition as the war of thirty years which occurred in Europe in the period from 1618 to 1648. In his latest book titlled "International Order", Henry Kissinger talks about this similarity, especially overlapping between the religious and political disputes that led to wars claimed the lives of the thousands of humans. Thus, the continuation of this situation in the Middle East will lead to the inflammation of confrontation like the religious wars that prevailed Europe in $17^{\text {th }}$ century(6). Also, Richard Haas, head of US Council on Foreign Relations, published an article on this subject. He stated that:" the Middle East now lives the early stages of the contemporary version of the war of thirty years where the political and religious loyalties foul conflicts within and among states". According to Hass," the region prepared for further unrest where its peoples is powerless politically and poor financially. It has no a future vision, the driving lines between the sacred and the secular are vague and disputable, and the national identity competes with identities steaming from religion, doctrine, and tribe. Furthermore, terrorism and armed militias have increasingly spread. Hass think that this struggle will be long, costly and deadly. As for as matters worsened, it is possible to worsen more in the future" (7).

Hence, a number of the American think tanks have a convection that it is better to leave the Middle East region pass the major transformation process that it witnesses. They argue that the region will be prevailed by inevitable troubles and instability for long time, and that the external interference will not change the transformation process in the region. Therefore, it is better to leave the region, and not to interfere in its affairs.

One of the indicators of the decline of the American interest in the Middle East in the Obama Administration is the decline of his foreign visits to the Middle East compared to his predecessor, Georg W. Bush. The number of Obama's foreign visits amounted to 29 times since the beginning of 2009 until the end of July 2013, including three times to the Middle East, while Georg W. Bush, the ex US president, visited the Middle East 11 times (8).

4- Furthermore, orientation towards Asia and the United States' fears of increased Chinese influence in Asia cannot be separated (9). The US fears of limiting its influence in Asia or exclusion it from interactions of China to rearrange Asia. To achieve this matter, the US needs to redistribute the degree of interest and American strategic potentials away from the Middle East and close to Asia (10). Susan Rise, the former adviser of US National Security, stated that: "President Obama gives a long time for the Middle East region. She added that the matter requires a degree of balance of all countries according to their important to US interests". This trend raised a broad controversy concerning the region's political reengineering and filling the vacuum that will result in reducing the expected American engagement in the affairs of the Middle East, and reconstructing the existence balance in the Middle East region and the extent of the effect of this matter on the other major powers in the context of Middle East's interactions (11).

The United States faces serious difficulties about putting the options of reducing of engagement in the Middle East into force because it may lose many economic and strategic advantages. In addition, the possibility that some major powers will be substitute for the United States in the context of the region's interactions and maps of influence and power. Furthermore, the difficulty of achieving security arrangement with the regional powers for developing the appropriate framework of regional balances which achieves security and stability. This matter will include extended negative effects that will impose direct and indirect threats on the United States. Thus, the Obama Administration forced to curb the American orientation towards Asia in the short term in order to avert its negative repercussions in the Middle East, and develop a plan to restructure the US role in the Middle East according to certain stages.

\subsection{Second, the Stages of the American Re-position in the Middle East}

The Obama Administration implemented the plane of restricting of the American role in the Middle East in the context of transformation from the Middle East to Asia - pacific region. This transformation occurred in two phases: the first occurred during Obama's first presidential term (from 2008 to 2012). The second occurred during Obama's second term (from 2012 till now). It is still continuous, and the nuclear agreement with Iran represents a part of this plan.

The analysis of the American dealing with the Middle East region during the two phases revealed general 
features and trends for this change, which are the following (12):

\subsubsection{The First Phase}

President Obama attempted, during his first term, to bridge the gap between the United States and the Muslim World, particularly the Middle East region. This orientation emerged in Obama's historical discourse at Cairo University (2009), and the campaign of public relations waged by the US administration in order to connect with the Middle East's people. Besides, steps that have been implemented to put an end to the American engagement in Iraq and Afghanistan by the gradual withdrawal from both, as well as the Obama Administration's plans to close Guantanamo Bay detention camp, which has not been closed so far. In addition, the United States has adopted methods and tools which were different from the direct military engagement in facing terrorism in the region, and depending basically on drones wars, and the intensification of intelligence and security dealing with the countries of the region.

\subsubsection{The Second Phase}

This phase associated with the endeavor of the Obama Administration to bring about a structural adjustment in the light of changing the strategic environment in the Middle East as a cocequence of the Arab revolutions, the collapse of the national state in a number of countries in the region, and transnational terrorism movements. Therefore, the Obama Administration reshaped dealing with the Middle East's crises and issues in the framework of holistic vision aiming to avoid getting involved in new wars. It also worked to push countries in the region to deal with the crises directly without dependence on the American role. In addition, it adopted a different strategy for dealing with Iran. This approach is consistent with turning the US administration from the Middle East and Europe to Asia - Pacific region. There are indicators that pointed out that the second term of the Obama Administration has represented shifting the focus towards Asia instead of the Middle East. The first indicator, the Obama Administration tried, at the beginning of its second term, to alleviate the external conflicts and crises as much as possible. At the same time, it tried to focus on the domestic affairs in order to rescue the US economy that came to the brink of collapse by reducing the enormous fiscal deficit in the budget and controlling the amount of the external debt, especially China. The second indicator, Obama visited, after being elected directly on November 2012, some Asian countries (Myanmar, Thailand, and Cambodia) in the same month. During his visit to these Asian countries, Israel launched a military operation against Gaza Strip, which was called as "the Pillar of cloud". Therefore, Obama sent Hillary Clinton, then foreign Minister, to Cairo to consolidate cease fire that has already been done on November 21, 2012. Thus, despite Obama's attempts to escape from the problems and troubles of the region, the events of the Middle East imposed itself on the agenda of the second administration. The third indicator embodied in Obama's nominations for John Kerry, Secretary of State, and Chulk Hagel, the Minister of Defense, in the second administration, which is interpreted by political analysts that new foreign trends of his administration will be based mainly on calm, non - interference, and staying away from adventures as much as possible(13).

\subsubsection{The US and Conflicts in the Middle East}

The US policy has shown a limited interest in Middle East's conflicts. This was part of the US' declined interest in the region. This matter has been dealt with in the following points:

\subsubsection{The Libyan Case}

The United States' intervention in dealing with the situation in Libya and the overthrow of the Gaddafi regime did not exceed lower limits to engage in the territory's affairs. It left the task for NATO and European allies, and merely managed the process from the back (14). Although the United States with the European forces succeeded in toppling the Gaddafi regime, conditions in Libya contributed to further instability in the region. Therefore, the Obama Administration with its European allies adopted a diplomatic and political process to push the Libyan parties to negotiate to establish a centralized state authority, regardless of the situations of the regional powers which prefer to deal with some factions but not with others. The Obama Administration is betting on stability in the Middle East in the long term. However, the problem lies in the lack of focus on the Libyan situation as the rest of Middle East's issues, and left it to the influence of the European Union. This matter demonstrates the evident difference in the pattern of the American political dealing with Middle East's issues. It adopted a different approach for each case separately according to the situation's requirements (15).

\subsubsection{The Syrian Case}

The US administration threatened Syria that it resorts to the military options to force Syria to stop using the Chemical Weapons. However, this threat was not actually implemented. It adopted the diplomatic option after consensus with international powers. It prefers decisiveness regarding the fate of the Syrian regime because it 
considers the strategic balances at the two regional and international levels. These balances include: facing the danger of the Islamic State of Iraq and Syria (ISIS) and not the Assad regime, and compatibility with Russia and China, allies of Assad, concerning the Syrian situation (16). In an interview with Jeffrey Goldberg in the Atlantic Journal, Obama did not find anything wrong with saying "I am extremely proud of my decision not to hit Syria despite criticisms faced by the US administration. He added: I deserve praise because I have a courage to avoid falling in potential swamp"(17). Thus, the American support for the Syrian people represented in supporting their aspirations for freedom without a real support for armed resistance against the regime of Bashar $\mathrm{Al}-\mathrm{Assad}$. It merely imposed sanctions on his regime (18).

\subsubsection{War on Terrorism}

Escalating the threats of ISIS to the American interests made the United States tended to lead an international coalition to fight it. However, the US administration preferred not to resort to the option of the comprehensive war as happened in the case of Iraq. It has adopted approach within an international coalition. It does not mention to mobilize an international action to dry up the organization's the sources of founding and to intensify the media war against the terrorist organization in order to prevent the accession of more fighters to it. Thus, the US administration adopted a selected option policy for combating terrorism. This matter is linked to the expansion of ISIS in Iraq and Syria and the announcement of the establishment of what is called "Islamic Caliphate State" in areas controlled by it. This matter reflected a qualitative shift in the armed Islamist groups' strategy where they shifted from non- state actors to a certain pattern of the state that have jurisprudence and vision concerning the nature and characteristics of the state. Although ISIS committed many massacres on the Iraqi and Syrian territories, the United States and its allies did not move seriously against it, only after the execution of American reporters by" ISIS"(19).

\subsubsection{Indirect Engagement}

In this interview with the American journalist, Thomas Friedman, published in New York Times Newspaper, on April 5, 2015, President Obama called the Arab States for dealing with the Syrian crisis, and not relying on the United States. He used the word "Sunni Arab State" for the first time. He has repeated the same approach when talked about democracy and human rights issues. He cited the concepts of the American liberals, who believe that the decline of democracy in the Middle East is the fundamental cause of terrorism. Obama stressed the need to adopt practices which address their problems related to democracy and human rights according to the American vision because these practices would eliminate the causes of terrorism (20).

Accordingly, the American interest and engagement in the Middle East declined. In return, it concentrated on Asia. However, this trend does not mean the United States withdrew entirely from the Middle East region where a degree of US interest in the region will remain for two main reasons. First, concerning Israel, the United States committed to maintain the existence and security of the Jewish state, which is one of the constants of US policy. Second, concerning oil, although the need of the United States to import oil from Middle East declined, his two allies, Japan and European Union, are still dependent on oil imports from the region. The United States will remain keen on continuing the flow of oil to its allies. There is another reason is that the United States keens to the availability of oil in the international markets with moderate prices. The United States has often coordinated with the Arab Gulf state in this regard. Consequently, any shake affecting the production or export of Gulf oil will lead to a rise in the price of oil in global markets, and then recession in the industrialized state and the global economy, which negatively affects the US economy (21).

\subsection{Third, Transformation towards Asia}

Broadly speaking, the US has shifted its economic and strategic focus towards Asia and Australia. These countries have a great importance because it represent about $50 \%$ of international economic growth, and represent a tremendous store of humans that can consume US goods. Therefore, the United States adopted a new strategic trend in its foreign policy, which makes a priority for the East politically, economically and militarily. The beginning of this trend was in 2010. After few months of the withdrawal of US troops from Iraq, in November 2011 during a official dinner in the Australian parliament, Obama said:" the United States will play a greater role in shaping the future of this region". Thomas Donilon, the National Security Adviser, said :" Obama's policy toward Asia does not mean focus only the priorities of the US foreign policy economically, militarily and diplomatically on the East and Southeast Asian countries, instead the US policy will focus on Middle and West Asia (Afghanistan and Iraq) (22).

\subsubsection{Motivations}

The reasons of this American transformation from the Middle East and Europe to Asia are: first, the United 
States has suffered from an economic and financial crisis in 2008. The Chinese and Asian banks played a key role in exceeding this crisis by buying the American and Western bonds. China and the rest of the Asian tigers have maintained considerable rates of economic growth during the global recession phase. These countries and others in Asia represent export opportunities for US companies. According to the reports of Central Intelligence Agency (CIA) issued in 2008, China will become the first economy in the world by 2025, meaning that there is a shift in the economic center of gravity from the West to the East, and the

possible shift of political gravity center to the East. Thus, the global economic influence leads necessary to the growing political one of the emerging countries of Asia (23). Second, the Indian economic growth raises the appetite of financial circles and entrepreneurship in the United States. Today, India occupies the seventh place among the largest ten economies in the world, surpassing Italy. This rapid growth in the second largest country in the world in terms of population means increasing a number of individuals affiliated to the middle class, which may represent a life collar for American companies internally and externally (24).

In 2010, total US exports to Asia exceeded the total exports to Europe for the first time in history. According to the US department of commerce statistics issued in 2014, there are eight Asian countries among the list of top twenty countries in terms of the trade exchange with the United States. Some Asian countries occupies advanced centers in terms of the trade exchange with the United States such as China (in the second place), and Japan (in the fourth place).

\subsubsection{The Dimension of the American Transformation towards Asia}

The orientation of the American foreign policy includes the Asia region based on diplomatic, economic military and strategic dimensions.

\subsubsection{The Diplomatic Dimension}

It is represented in high - level diplomatic contacts by senior US officials' visit to the countries of the region, including the President, the Secretary of State and Defense Minister. The visit of both the former US Secretary of State, Hillary Clinton, and the current minister, John Kerry to East Asia were numerous compared with the former foreign minister visits (25). Hillary Clinton was the first American foreign ministers who visited all Southeast Asian countries during its mandate. In addition, the diplomatic dimension focuses on strengthening relations with historic allies and friends of the United States, in particular Japan and South Korea. Also, the United States is seeking to play a greater role in regional organization in the region. This trend has been evident in 2011 by several high - level diplomatic initiatives. For example, the United States hosted the summit of the organization of economic cooperation for Asia and the Pacific, the Washington declaration on the deployment of Marines in Northern Australia, and the presence of President Obama of the first summit of East Asian countries.

It is clear that these initiatives are designed to deliver a message to public opinion in the United States and Asia on both the size and depth of the US interest in the continent. The United States has healed the reft of relations with Burma (Myanmar), and even President Obama visited the Capital, Rangoon, just two weeks after his re-election, to be the first US president who visiting it. Obama announced just days before his visit that the United States will allocate about 170 million dollars for developmental projects in Myanmar over the next two years. Obama also visited both Thailand and Cambodia during his Asian tour (26). Before leaving the White House, Obama has toured Asia, including Vietnam and Japan. He visited Hiroshima city to be the first US president visiting it.

\subsubsection{The economic dimension}

The United States is trying to deepen trade cooperation with East Asia countries by building economic relations with them and minimizing China's economic role and reducing its rise. The biggest proof of that matter was to the United States has signed, in early October 2015, a partnership agreement across the Pacific with eleven countries overlooking the Pacific Ocean, namely: Australia, Brunei, Chile, Japan, Malaysia, Mexico, New Zealand, Peru, Singapore, and Vietnam with exception of China. It is multilateral free trade agreement, which aims to increase the liberation of Asia - Pacific economies. Therefore, President Obama said "Washington would not allow writing the rules of the global economy by a country like China (27). When more than $95 \%$ of our potential consumers live outside our borders, then it could not make countries like China to write the rules of the global economy. He added that we should write these rules, and open new markets for US products as we develop high standards to protect our workers and preserve our environment" (28).

This partnership is more than just a free trade area. It is not similar to the European Union exactly, but it heralds new rules on the level of coordination and economic integration among the peoples of member states and synchronize the social policies in these states. It is capable of restricting the scene of the international political 
economy and the policies of the world for the coming years and decades (29). As a key step to reform and develop the international regulations in Post - Cold War period, trans-pacific partnership will provide and establish many new standards and mechanisms to promote and organize trans -borders activities, which have very high and comprehensive standards credited by World Trade Organization (30).

This ambition and institutional edifice led by the United States includes states overlooking the Pacific Ocean. They are among the largest and most active economies in the world such as Australia, Brunei, Canada, Chile, Japan, Malaysia, Mexico, New Zealand, Peru, Singapore, the United States and Vietnam. The partnership covers nearly $40 \%$ of global GDP, and $44 \%$ of the total US goods exports. Thus, this partnership has been established to expand geographically and politically, and to be more comprehensive and effective, particularly at the level of international presence. Talking into account the Trans-Atlantic Trade and Investment partnership (TTIP) being negotiated between the United States and the European Union at the same time and with stimulate from the Pacific partnership, the latter is an indicator to the advent of a new world economic order. In general, the two partnership herald more liberal trade and economic growth, as well as enhance integration and the continuous reform among Member States, and thus re-formulate and promote the economic and financial leadership of the West led by the United States (31).

\subsubsection{The Military Dimension}

The US seeked to increase its military presence in the region. Also, it seeks to re-distribute its military fleet to concentrate the largest part of the destroyers, submarines and aircraft carriers in the Pacific. These forces were divided between the two Pacific and Atlantic Oceans, but the US currently seeks to re-distribute these forces by concentration of $60 \%$ of the fleet in the Pacific region. Furthermore, the US has increased the number of joint exercises with the countries of the region. Also, it has increased the US ships visits to Asian ports. For example, in the spring of 2012, the US Navy conducted extensive exercises with the Philippines, which suffered from border disputes with China in China South Sea. There is now a talk about re-presence of US military in the naval base at "Subic Bay" in the Philippines, from which the United States has been expelled by the Philippines in 1992. There is even worse than that matter where Admiral Harry Harris, the top US commander in the region Pacific, announced that the US plans to direct military action by increasing the US Naval patrols in the South China Sea, which actually happened in November 2015 when US destroyer passed near a set of the artificial islands set up by China near the "Spratly" islands, which is disputed between China and Taiwan, Vietnam, the Philippines, Malaysia and Brunei. The US enhanced the military ties with Vietnam that suffers, also, from border disputes with China (32). In addition, the United States enhanced the military presence at its bases in Japan, South Korea, and deployed US Marines in Western Australia. The previous matters are an integral part of Pentagon's new military principle, which is navy - air battle. It focuses on the integration of navy and air forces in order to deter China or any potential enemy from obstructing US military operations in the Pacific Ocean (33).

The United States also enhanced its cooperation in the areas of military industrialization and technology exchange with India. US policy towards India is at the heart of its strategy based on powers balance where India is the most important regional power that counterweighs to China. Obama administration has given the priority to India at the expense of Pakistan, the United States' allay. This matter has great connotations. Washington's cooperation with India economically, militarily and diplomatically reached unprecedented levels during the last ten years. Both Bush and Obama administrations were very cautious regarding absorbing the sensitivity of India in the two critical areas, which are nuclear power in India and the Kashmir dispute with Pakistan.

There is no doubt that China is the most important priorities of the United States in its transformation towards the Asia-Pacific region. The American approach towards China aims to containment and participation at the same time. The economic and political dynamics support the logic of participation. On the other hand, the military dynamics achieve the logic of containment. Globalization poses the necessity of participation. In addition, the United States believes that the economic participation will lead to the achievement of democracy in China. According to this doctrine, the spectacular economic growth of China will ultimately lead to a democratic transition in the country (34).

\subsubsection{The strategic dimension}

Competition between the United States and China became evident due to the approach adopted by US towards Asia. China has been able to promote the political and economic influence on the continent due to the involvement of the United States in the wars in Iraq and Afghanistan. Beijing's Policies in South China Sea and East China Sea raised concerns of traditional US allies, particularly Japan and South Korea. Thus, any absence of prominent American role is equivalent to China's influence, and will push a lot of countries in the region for acknowledging the dominance of China on the East Asia region. Also, this American trend raised a degree of 
discontent in the Chinese circles, considering that the American extension in the continent aims to deprive China of expanding in its close vital era. They considered the US orientation as a modified version of containment policy pursued by the United States against the Soviet Union during the Cold War.

Furthermore, it appears that the United States is concerned about the growing cooperation between Asian countries that may lead to establish a giant Asian economic entity from which the United States excluded. For example, the United States is concerned about what is called the Association of Southeast Asian Nations (ASEAN), which has resorted, since the Asian monetary crisis in 1997, to deepen cooperation with China, Japan and South Korea. These countries do not hide their desire to create the East Asian Organization like the European cooperation organization, which was the first nucleus of the European Union. Such integration efforts show the desire of unremitting Asian countries in achieving the economic integration between the countries of the continent. Indeed, some politicians began to raise political slogans like "Asia first", which exclude non Asian countries spearheaded by the United States (35).

The personal factor also plays a key role in promoting the American orientation towards Asia where Obama was born in Hawaii, the closest state to Asia continent. Also, he spent a part of his initial years in Indonesia. These self experiences, of course, affected the trends of the US foreign policy. In addition, Obama wanted to take the United States away from the focus of his predecessor, President George W. Bush on the regions of Central and West Asia.

\section{Conclusion}

Certainly, Obama has realized various historical achievements for his country at the level of foreign policy. However, the most significance achievement, according to the perspective of the US administration is rapid signing and ratification of Trans-Pacific partnership Agreement (TPPA). This agreement created new future prospects for the US role in a promising and important Asia region. It has been activated by the Obama administration's frequent visits to several important Asian countries.

Despite the fact that most economists and military leaders do not hide their support for the US interest in the Asian continent in $21^{\text {st }}$ centuey, but there are voices warning of the fact that such policy will lead to push China to adopt hostile policies against the United States because it attempts to curb the world's largest country in terms of population. These experts believe that this trend resulting in open conflict with China is not in the interest of the United States currently and in the future. In fact, China has responded by challenging the interests of the United States outside of East Asia. When China voted in the UN Security Council between 2006- 2010 in favor of imposing sanctions on Iran, Beijing has threatened to use the right of veto against a draft resolution to impose sanctions on Iran's oil exports. In addition, when the United States, Japan and European countries agreed to impose these sanctions outside the framework of the Security Council, Beijing concluded new deals with Iran to buy its oil. China sided with Russia against the United States, which wanted to impose sanctions on Damascus. It seems that the Obama administration is aware of the danger of this trend, and that Senior US officials was keen to stress that the American orientation towards Asia is not direct against Beijing. Nevertheless, it is clear that there is a price the United States should pay for the adoption of such Asian politics. It is not excluded that the current administration of Trump reconsiders this policy in the light of the international changes in general, and developments in East and south Asia in particular. Eagerly, all look at President Trump to know approach adopted by him towards various international issues so that they could know the style of his dealing with the Asian files. Obama has given a new active role to the Asian states with regard to developing the future policies of various fields.

Many Asian partners have doubts about the extent of the next US president's commitment to the new Asian strategy adopted by Obama. They do not hide their fear of the determination of the new President to turn the attention of the United States from Asia to other regions of the world such as Africa or Latin America. Previously, the republican candidate Donald Trump stated that many of the US-allied countries in Asia have to pay more in return for the commitment of the US to save their own security and the development of their weapons to protect them from the ongoing threats of North Korea and China. However, the few months Trump has spent at the White House since 20 January, 2017 are not enough to define a clear strategy of the US. Apprehensively, the Asian states look at the next President. They ask whether the next President will develop what Obama has begun and will start from Obama ended, or he will consider this nascent strategy. However, the strategic orientation based on the reduction of the engagement in the Middle East, and disengagement from its issues will continue.

\section{References}

Barak, O. (October, 2015). Statement by the President on the Trans-Pacific Partnership. The white house, Office of the Press Secretary, released. 
David, S. (July - August, 2015). China's Soft-Power Push. Foreign Affairs.

Derek, C. (2016). The Long Game: How Obama Defied Washington and Redefined America's Role in the World. New York: Public Affairs.

Fawaz, A. G (2012). Obama and the Middle East: the End of America's Moment? (New York, NY: Palgrave Macmillan.

Fei, L. W. (2016). China and partnership across the Pacific: Challenges and opportunities. Aljazeera Centre for Studies.

Fred, K. (January - February, 2016). Obama's way: the president in practice. Foreign Affairs.

Hossam, I. (2015). Integrating Iran: US policy toward the Middle East after the nuclear deal with Iran. Haelet El - Eklim Magazine, 16.

Jackie, C. (October, 2015). 11 Pacific Nations and U.S. Endorse Giant Trade Pact. The New York Times.

Juan, C. (2014). The US policy in the Middle East in Barack Obama's second presidential term. Abu Dhabi: The Emirates Center for Strategic Studies and Researches, p.6.

Lillian, E. K. (2016). Pereception as a Foreign Policy resources: A Study of Obama's perception impact on the American foreign policy towards the Middle East (PH.D thesis, pp. 178-180).

Mahmoud, H. (2013). The US and the Strategic trend Towards the East: Opportunities and Challenges. Aljazeera Centre for Studies.

Mohamed, K. (2014). Kissinger and the international system. Afak Siyasia Magazine, 12, 48.

Mohamed, K. (2016). US policy and the Middle East: limits of continuity and change. Al-Siyassa Al-Dawliya Magazine, 203, 122.

Mohamed, M. (2013). Renewed priorities: Trend of second Obama a administration towards the Middle East. $\mathrm{Al}$ - Siyassa Al-Dawliya Magazine, 193, 43.

Mohamed, S. A. (2015). Difficult options: the future of US policy in the Middle East. Al-Siyassa Al-Dawliya Magazine, 199, 73.

Mohamed, S. A. (2015). The American - Chinese competition in South China Sea. El Khaleg El - Emirates newspaper.

Mustafa, A. M. (2016). Obama doctrine and Unmask US Policy Oreintations. She'on Arabia periodical, 166, 18.

National Security Strategy of THE United States of America. (February 6, 2015). http://nssarchive.us/wp-content/uploads/2015/02/2015.pdf

National Security Strategy of THE United States of America. (May 27, 2010). http://nssarchive.us/NSSR/2010.pdf

Orientations of US foreign Policy towards the Regions of the World: Activating the Strategic Orientation towards the Asia- Pacific, The Arab Strategic report, 2015, 55.

S, Mahmud. A. (2012). Asia - pacific Security Dynamics in the Obama Era: A new Word Emerging. Rutledge, New York.

Sherif, S. M. (2016). Containment and partnership: US Strategy in Asia.

The Arrangement of the World States Economically in 2015 according to GDP.

The Middle East and the Post- America. (2013).

The US policy in the Pacific and East Asia. (2016).

USTR. (2015). Trans-Pacific Partnership. https://ustr.gov/tpp/

Vali, N. (2013). The Dispensable Nation: American Foreign Policy in Retreat. New York: Anchor.

\section{Copyrights}

Copyright for this article is retained by the author(s), with first publication rights granted to the journal.

This is an open-access article distributed under the terms and conditions of the Creative Commons Attribution license (http://creativecommons.org/licenses/by/4.0/). 